\title{
KERAGAMAN ARTHROPODA PADA SACHA INCHI DI LAHAN KERING
}

\author{
Khairun Nisa, Retno Wijayanti* dan Endang Setia Muliawati \\ Program Studi Agroteknologi, Fakultas Pertanian, Universitas Sebelas Maret \\ *Corresponding author: retnowijayanti@staff.uns.ac.id
}

\begin{abstract}
Dryland is one of the most potential ecosystems for cultivated land. Sacha inchi (Plukenetia volubilis L.) is perennial plant originated from Peru and spread to the tropic area like China and Thailand. Arthropods in the plants can be a role as a pest, natural enemy, decomposer, and pollinator. This research purposed to specify diversity of Arthropods and its role in sacha inchi crop. This research has been carried out in June to December 2015 in Mojosongo, Kebak, Jumantono, Karanganyar, Central Java and Laboratory of Plant Pests and Diseases, Faculty of Agriculture, University of Sebelas Maret Surakarta. The observation was implemented using absolute methods. Data were analyzed by descriptively about the diversity and the abundance of Arthropods on the sacha inchi plants. The result showed that on sacha inchi plant there were 75 families Arthropods consist of 13 orders those are Araneae, Ephemeroptera, Odonata, Orthoptera, Blattaria, Isoptera, Hemiptera, Homoptera, Thysanoptera, Coleoptera, Diptera, Lepidoptera, and Hymenoptera. The role of Arthropods on sacha inchi plant $8 \%$ as pest, $10 \%$ as the natural enemy (predators and parasitoids), and $82 \%$ others (decomposers and pollinators). The family diversity of the Arthropods was a low category (ShannonWeaver index is 0.692) and Pielou evenness index is 0.164 so Arthropods' evenness was low.
\end{abstract}

Keywords: Evenness; Natural enemy; Pest; Potency

Cite this as: Nisa, K., Wijayanti, R., \& Muliawati, E. 2017. Keragaman Arthropoda pada Sacha Inchi di Lahan Kering. Caraka Tani: Journal of Sustainable Agriculture. 32(2), 132-141. doi: http://dx.doi.org/10.20961/carakatani.v32i2.16330

\section{PENDAHULUAN}

Lahan kering merupakan salah satu agroekosistem yang berpotensi besar untuk usaha pertanian baik tanaman pangan, hortikultura, maupun tanaman tahunan dan peternakan (Abdurachman et al., 2008). Luas lahan kering Indonesia 63,4 juta ha (BPS, 2010) diantaranya tidak digunakan antara lain berupa semak belukar seluas 9,7 juta ha. Oleh karena itu perlu meningkatkan pemanfaatan lahan tersebut sehingga dapat menambah kesejahteraan khususnya para petani di Indonesia. Pemanfaatan lahan kering dapat melalui penanaman berbagai komoditas yang potensial dikembangkan, salah satu adalah sacha inchi.

Menurut Hamaker et al. (1992), sacha inchi memiliki banyak nutrisi yang sangat bermanfaat bagi tubuh karena mengandung Omega $345,2 \%$, Omega 636,8\%, Omega 9 9,6\%, dan 7,7\% lemak jenuh. Di Indonesia, tanaman ini belum diusahakan secara luas sehingga perlu diadakan uji coba terlebih dahulu. Tanaman sacha inchi merupakan tanaman introduksi sehingga perlu penelitian mengenai organisme penganggu yang mungkin menyerang. Fillum Arthopoda memiliki berbagai peran dalam kelangsungan hidup tanaman, sebagai hama, musuh alami, atau penyerbuk. Tujuan penelitian untuk mempelajari keragaman dan peran Arthropoda pada pertanaman sacha inchi.

\section{METODE PENELITIAN}

Penelitian dilaksanakan mulai bulan Juni sampai Desember 2015 di Mojosongo, Kebak, Jumantono, Karanganyar, Jawa Tengah dan Laboratorium Hama dan Penyakit Tanaman Fakultas Pertanian Universitas Sebelas Maret Surakarta. Jenis tanah tempat percobaan litosol dan elevasi 110 mdpl. Biji sacha ichi ditanam pada kebun dengan luas $22 \times 4 \mathrm{~m}$. Sebelum ditanam, tanah diolah menggunakan cangkul dan dibuat guludan. Jarak antar guludan $1 \mathrm{~m}$. Pada Lubang tanam dibuat di sepanjang guludan dengan jarak antar lubang $60 \mathrm{~cm}$. Setiap lubang 
ditanami 1 biji sacha inchi, dan ditutup dengan pupuk kandang. Pemupukan berikutnya dilakukan dua kali saat tanaman fase vegetatif dengan cara memberikan pupuk di sekitar lubang tanam. Pada penelitian ini hanya digunakan pupuk kandang dan tidak dilakukan penyemprotan pestisida.

Pengamatan dilakukan dengan metode mutlak. Pengamatan pada saat tanaman sudah tumbuh tinggi (merambat), hanya sampai setinggi mata peneliti $(100 \mathrm{~cm})$. Athropoda di tanaman langsung diidentifikasi di lapangan, sebagian dimasukkan ke flakon atau toples berisi alkohol $70 \%$ untuk diidentifikasi di laboratorium dengan menggunakan kunci determinasi Arthropoda menurut Borror et al. (1992) dan kunci determinasi serangga (Lilies 2008). Arthropoda hasil identifikasi kemudian dikelompokkan berdasarkan ordo untuk menghitung kelimpahan, keragaman, dan kemerataan famili Fillum Arthropoda tersebut. Keragaman famili dihitung dengan Indeks Shanon-Weaver (1963) dalam Beisel et al. (2003) sedangkan kemerataan famili dengan Indeks Pielou (1966) dalam Beisel et al. (2003):

$$
\mathrm{H}^{\prime}=-\Sigma(\mathrm{qi} / \mathrm{Q}) \ln (\mathrm{qi} / \mathrm{Q})
$$

Keterangan:

H' = Indeks Keragaman Shannon-Weaver

Qi = Kelimpahan taxa (takson level, dalam penelitian ini famili) ke-i

$\mathrm{Q}=$ Jumlah total individu dalam komunitas

Menghitung Index Kemerataan Pielou:

$$
E_{\text {Pielou }}=H^{\prime} / H^{\prime} \max
$$

Keterangan:

$E_{\text {Pielou }}=$ Indeks Kemerataan Pielou

$\mathrm{H}^{\prime}{ }_{\text {max }}=\ln \mathrm{S}$

$\mathrm{H}^{\prime}{ }_{\max }=$ Indeks Keragaman maksimal ShannonWeaver

$\mathrm{S} \quad=$ jumlah taxa (famili) dalam komunitas

\section{HASIL DAN PEMBAHASAN}

\section{Kondisi Umum Penelitian dan Karakteristik Sacha Inchi}

Kondisi lahan saat penelitian bersih dari tumbuhan lain. Di sekeliling lahan terdapat pohon jati Tectona grandis (Verbenaceae), bambu Bambusa vulgaris (Poaceae), nangka Artocarpus heterophyllus (Moraceae), durian Durio zibethinus (Malvaceae), rambutan Nephelium lappaceum (Sapindaceae), kelapa Cocos nucifera (Araceae), dan pisang Musa paradica (Musaceae). Saat penelitian dimulai, kondisi lokasi percobaan kering, namun saat penelitian berlangsung turun hujan yang dimulai pertengahan November 2015. Beberapa tanaman yang tumbuh di lahan dan sekitarnya yaitu petai Parkia speciosa (Fabaceae), rumput gajah Cenchrus purpureus (Graminaceae), babandotan Ageratum conyzoides (Asteraceae), kencur Kaempferia galanga (Zingiberaceae), jambu biji Psidium guajava (Myrtaceae), bunga warna ungu (Melastomataceae), pakan ular Zingiber montanum (Araceae), bunga terompet (Apocynaceae), dan putri malu Mimosa pudica (Fabaceae). Selain itu juga ada tanaman jagung Zea mays (Poaceae) yang ditanam pada sebelah selatan lahan.

Tabel 1. Data Curah Hujan, Suhu, Kelembapan Kecamatan Jumantono Tahun 2015

\begin{tabular}{clccc}
\hline No. & \multicolumn{1}{c}{ Bulan } & Curah Hujan $(\mathrm{mm})$ & Suhu Rata-Rata $\left({ }^{\circ} \mathrm{C}\right)$ & Kelembapan $(\%)$ \\
\hline 1. & Januari & 223 & 26,6 & 83,1 \\
2. & Februari & 492 & 27,5 & 81,1 \\
3. & Maret & 524 & 27,4 & 82,3 \\
4. & April & 429 & 27,3 & 84,0 \\
5. & Mei & 68 & 27,4 & 78,4 \\
6. & Juni & 0 & 27,5 & 71,9 \\
7. & Juli & 0 & 27,6 & 68,8 \\
8. & Agustus & 0 & 26,9 & 72,4 \\
9. & September & 0 & 27,4 & 70,0 \\
10. & Oktober & 4 & 27,6 & 67,5 \\
11. & November & 172 & 28,6 & 75,5 \\
12. & Desember & 486 & 27,7 & 81,1 \\
\hline
\end{tabular}

Sumber: Stasiun Puslitbang Fakultas Pertanian UNS 
Sacha inchi merupakan tanaman terna perennial yang merambat yang termasuk family Euphorbiaceae. Menurut Mwine dan Van Damme (2011), anggota family ini tersebar secara luas dan memiliki habitat yang kompleks. Benih sacha inchi yang disemai pada bulan Juni 2015 kemudian ditanam di lahan pada bulan Juli 2015. Tanaman ini mulai muncul bunga pada pertengahan September 2015 yang berumur 3,5 bulan. Hal ini berbeda dengan penelitian Yang et al. (2014), sacha inchi mulai berbunga 16 bulan setelah semai sedangkan pada penelitian Cai et al. (2013), sacha inchi sudah berbunga pada 8 bulan setelah semai dengan masa masak buah 4 bulan setelah berbunga Perbedaan panjang hari kemungkinan penyebab perbedaan umur fase vegetatif sacha inchi. Buah sacha inchi mulai muncul pada bulan Oktober 2015 dan dapat dipanen pada bulan Desember 2015 yang ditandai dengan buah yag berubah warna menjadi kecoklatan seperti pada gambar $1 \mathrm{~F}$.
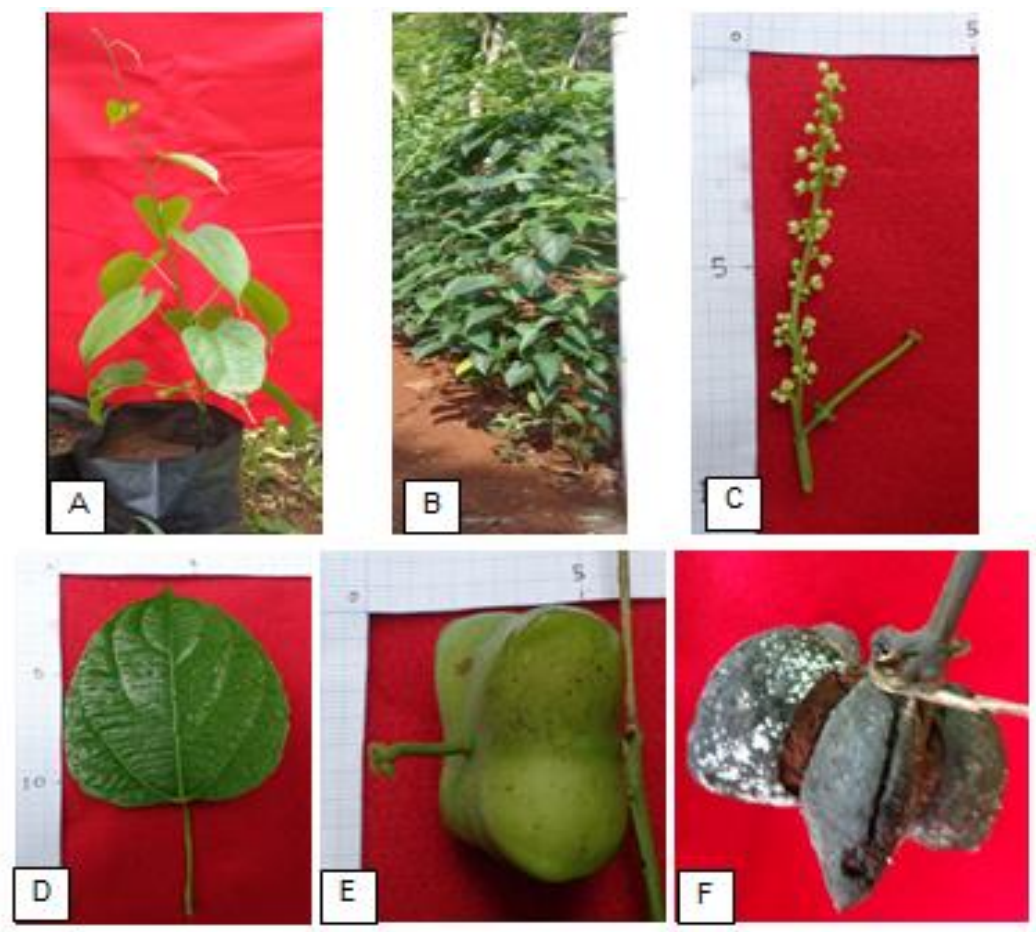

Gambar 1. A-B. Tanaman Sacha Inchi. C. Bunga Sacha Inchi. D. Daun Sacha Inchi. E. Buah Sacha Inchi. F. Buah Sacha Inchi Siap Panen

\section{Keragaman Arthropoda}

Arthropoda merupakan hewan yang di alam keberadaannya melimpah, memiliki berbagai peran di pertanaman antara lain sebagai herbivor, musuh alami, dekomposer/pengurai, dan penyerbuk. Di pertanaman sacha inchi, jumlah organisme paling banyak dari ordo Hymenoptera berjumlah 9.966 ekor pada fase vegetatif dan 5.958 ekor serta 10 koloni pada fase generatif (Tabel 2). Hymenoptera paling tinggi dibanding ordo lain karena sebagian besar berupa semut yang merupakan serangga sosial, hidup sebagai pemakan bahan organik selain juga makan cairan sacha inchi. Diptera menjadi ordo berjumlah paling tinggi kedua dan Araneae paling tinggi ketiga. Ini karena keduanya merupakan ordo yang sangat berkaitan dengan keseimbangan ekosistem. Keseimbangan terjadi karena peran sebagai predator, pollinator (fase generatif) dan juga sebagai hama sacha inchi, pengurai bahan organik di lingkungan pertanaman, sedangkan ordo lain menjadi mangsa predator tersebut selain memakan tanaman sacha inchi.

Jumlah Arthropoda dalam suatu lingkungan dipengaruhi oleh banyak faktor. Menurut Komi et al. (2015), faktor yang berpengaruh tersebut dapat dikelompokkan sebagai faktor dalam (fisiologi) dan faktor luar (lingkungan tempat tinggal). Faktor luar berupa berupa makanan yang tersedia di alam, suhu, kelembapan udara, musuh alami, dan kompetisi dalam mencari makanan. 
Tabel 2. Jumlah Individu setiap Famili dari Fillum Arthropoda yang ditemukan di Pertanaman Sacha Inchi selama 18 Pengamatan (5-22 MST)

\begin{tabular}{lccccc}
\hline \multirow{2}{*}{ Ordo } & \multicolumn{2}{c}{ Vegetatif } & \multicolumn{2}{c}{ Generatif } & \multirow{2}{*}{ Total } \\
\cline { 2 - 5 } & $\Sigma$ Famili & $\Sigma$ Individu & $\Sigma$ Famili & $\Sigma$ Individu & \\
\hline Araneae & 8 & 907 & 10 & 585 & 1.492 \\
Ephemeroptera & 1 & 1 & 0 & 0 & 1 \\
Odonata & 0 & 0 & 1 & 1 & 1 \\
Orthoptera & 4 & 17 & 4 & 37 & 54 \\
Blattaria & 1 & 1 & 1 & 1 & 2 \\
Isoptera & 0 & 0 & 1 & 1 & 1 \\
Hemiptera & 2 & 3 & 2 & 9 & 12 \\
Homoptera & 8 & 342 & 7 & 341 & 683 \\
Thysanoptera & 1 & 6 & 1 & 3 & 9 \\
Coleoptera & 8 & 112 & 8 & 454 & 566 \\
Diptera & 19 & 71 & 20 & 2.715 & 2.786 \\
Lepidoptera & 6 & 95 & 6 & 65 & 160 \\
Hymenoptera & 4 & 9.966 & 5 & 5.958 & 15.924 \\
\hline
\end{tabular}

Perbedaan ekosistem akan berpengaruh terhadap keragaman dan kemerataan Arthropoda yang ada di dalamnya. Hal ini dapat disebabkan oleh banyak faktor, di antaranya suhu, kelembapan, organisme lain dan faktor fisiologis.

Tabel 3. Keragaman dan Kemerataan Famili dari Fillum Arthropoda di Pertanaman Sacha Inchi

\begin{tabular}{cccc}
\hline Indeks & Vegetatif & Generatif & Keterangan \\
\hline H' & 0,339 & 0,353 & Keragaman Rendah \\
E & 0,080 & 0,084 & Kemerataan Rendah \\
\hline
\end{tabular}

H': Indeks Keragaman Shanon-Weaver, E: Indeks Kemerataan Pielou

Indeks keragaman dan kemertaan famili dalam filum Arthropoda pada pertanaman sacha inchi pada fase vegetatif dan generatif termasuk rendah (Tabel 3). Berdasarkan kriteria Maulina et al. (2016), keragaman rendah apabila $\mathrm{H}<1$; sedang apabila $\mathrm{H}=1-3$; dan tinggi jika $\mathrm{H}>3$. Sementara menurut Oktiana dan Antono (2015) kemerataan termasuk tinggi bila $\mathrm{E} \geq 0,6$, sedang bila $0,4<\mathrm{E} \leq 0,6$ dan rendah bila $0<\mathrm{E} \leq 0,4$. Keragaman rendah dapat disebabkan oleh jumlah populasi suatu famili lebih tinggi daripada variasi populasi tersebut sedangkan kemerataan rendah menunjukkan bahwa populasi dari suatu famili di pertanaman sacha inchi tidak merata sehingga famili Fillum Arthropoda berada dalam kemerataan rendah.

Tabel 4. Jumlah Total Individu setiap Famili dari Ordo Araneae yang ditemukan di Pertanaman Sacha Inchi selama 18 Pengamatan (5-22 MST)

\begin{tabular}{lccccc}
\hline \multicolumn{1}{c}{ Famili } & Vegetatif (ekor) & Generatif (ekor) & Total (ekor) & Persentase $\%$ & Peran \\
\hline Salticidae & 262 & 533 & 795 & 44,31 & Predator \\
Araneidae & 533 & 165 & 698 & 38,91 & Predator \\
Amaurobiidae & 13 & 6 & 19 & 1,06 & Predator \\
Oxyopidae & 11 & 52 & 63 & 3,51 & Predator \\
Thomisidae & 19 & 26 & 45 & 2,51 & Predator \\
Linyphiidae & 3 & 2 & 5 & 0,28 & Predator \\
Dysderidae & 1 & 1 & 2 & 0,11 & Predator \\
Diguetidae & 65 & 96 & 161 & 8,97 & Predator \\
Pisauridae & 0 & 5 & 5 & 0,28 & Predator \\
Dictynidae & 0 & 1 & 1 & 0,06 & Predator \\
\hline
\end{tabular}


Di alam, keseimbangan populasi organisme dipengaruhi kombinasi faktor fisik dan biotik (Daly et al., 1978). Keragaman rendah menunjukkan tingkat trofik kurang kompleks sehingga kestabilan ekosistem rendah. Berdasar hasil penelitian, populasi Arthropoda didominasi kelompok pengurai (Gambar 4) sehingga tidak menimbulkan kerugian dalam budidaya sacha inchi. Curah hujan, suhu, dan kelembapan merupakan faktor yang mempengaruhi keragaman dan kemerataan famili dari Fillum Arthropoda di pertanaman sacha inchi.

Salticidae dan Araneidae merupakan dua famili laba-laba berjumlah paling tinggi (Tabel 4). Salticidae merupakan tipe laba-laba peloncat, mencari korban pada siang hari. Araneidae merupakan laba-laba yang menangkap mangsa dengan membuat sarang berbentuk lingkaran dan menunggu mangsa. Ketika ada organisme tertangkap oleh jaring, maka laba-laba ini kemudian segera menangkap.

Diguetidae dan Araneida memiliki sarang seperti kerucut untuk menangkap mangsa dan mempertahankan diri dari serangan predator. Menurut Nyffeler (1999), laba-laba pembuat sarang merupakan predator tidak bergerak yang menunggu mangsa datang ke sarang, sedangkan laba-laba pemburu mencari mangsa baik yang bergerak maupun diam.

Tabel 5. Jumlah Total Individu setiap Famili dari Ordo Orthoptera yang ditemukan di Pertanaman Sacha Inchi selama 18 Pengamatan (5-22 MST)

\begin{tabular}{lccccc}
\hline Famili & Vegetatif (ekor) & Generatif (ekor) & Total (ekor) & Persentase (\%) & Peran \\
\hline Gryllidae & 1 & 0 & 1 & 1,85 & Hama \\
Acrididae & 12 & 7 & 19 & 35,19 & Hama \\
Phyrgomorphidae & 0 & 3 & 3 & 5,56 & Hama \\
Mantidae & 2 & 4 & 6 & 11,11 & Predator \\
Tettigoniidae & 2 & 23 & 25 & 46,30 & Predator \\
\hline
\end{tabular}

Famili Acrididae banyak ditemukan pada fase vegetatif, sedangkan saat fase generatif banyak ditemukan famili Tettigoniidae (Tabel 5). Menurut Daly et al. (1978), Acrididae merupakan hama penting di lahan kering. Hama ini memakan tanaman budidaya maupun tanaman liar. Tettigoniidae merupakan predator, sehingga tingginya populasi akan menguntungkan pada pertanaman sacha inchi.

Tabel 6. Jumlah Total Individu setiap Famili dari Ordo Homoptera yang ditemukan di Pertanaman Sacha Inchi selama 18 Pengamatan (5-22 MST)

\begin{tabular}{lccccc}
\hline Famili & Vegetatif (ekor) & Generatif (ekor) & Total (ekor) & Persentase (\%) & Peran \\
\hline Flatidae & 3 & 7 & 10 & 1,46 & Hama \\
Aphididae & 168 & 134 & 302 & 44,22 & Hama \\
Aleyrodidae & 159 & 56 & 215 & 31,48 & Hama \\
Coccidae & 1 & 131 & 132 & 19,33 & Hama \\
Fulgoridae & 2 & 0 & 2 & 0,29 & Hama \\
Psyllidae & 1 & 7 & 8 & 1,17 & Hama \\
Meenoplidae & 4 & 4 & 8 & 1,17 & Hama \\
Derbidae & 4 & 2 & 6 & 0,88 & Hama \\
\hline
\end{tabular}

Diantara ordo Homoptera, Famili Aphididae paling banyak ditemukan pada pertanaman sacha inchi diikuti Aleyrodidae dan Coccidae (Tabel 6). Aphididae merupakan serangga yang memiliki lebih dari 40 famili tanaman inang. Menurut Gonsebatt et al. (2012), Aleyrodidae merupakan serangga polifag yang makan cairan dalam jumlah besar sedangkan Coccidae merupakan hama pada berbagai tanaman budidaya (Williams dan Kosztarab 1972). Beragamnya kisaran inang ketiga famili ini menjadikannya lebih banyak ditemukan di pertanaman sacha inchi dibandingkan famili lainnya. 
Tabel 7. Jumlah Total Individu setiap Famili dari Ordo Coleoptera yang ditemukan di Pertanaman Sacha Inchi selama 18 Pengamatan (5-22 MST)

\begin{tabular}{lccccc}
\hline \multicolumn{1}{c}{ Famili } & $\begin{array}{c}\text { Vegetatif } \\
\text { (ekor) }\end{array}$ & $\begin{array}{c}\text { Generatif } \\
\text { (ekor) }\end{array}$ & $\begin{array}{c}\text { Total } \\
(\text { ekor })\end{array}$ & $\begin{array}{c}\text { Persentase } \\
(\%)\end{array}$ & Peran \\
\hline Staphylinidae & 4 & 1 & 5 & 0,88 & Predator \\
Coccinellidae & 17 & 20 & 37 & 6,54 & Hama, Predator \\
Chrysomelidae & 36 & 227 & 263 & 46,47 & Hama \\
Carabidae & 3 & 39 & 42 & 7,42 & Hama \\
Curculionidae & 30 & 94 & 124 & 21,91 & Hama \\
Phalacridae & 20 & 62 & 82 & 14,49 & Hama \\
Apionidae & 1 & 8 & 9 & 1,59 & Hama \\
Elateridae & 0 & 3 & 3 & 0,53 & Hama \\
Cantharidae & 1 & 0 & 1 & 0,18 & Hama \\
\hline
\end{tabular}

Coleoptera cenderung lebih banyak ditemukan pada fase generatif, hal ini menunjukkan kelompok hama ini lebih tertarik saat tanaman sudah muncul bunga (Tabel 7). Chrysomelidae dan Curculionidae paling banyak ditemukan. Kedua famili ini merupakan hama pemakan daun yang ditemukan pada semua fase pertumbuhan tanaman. Selain sebagai sumber pakan, sacha inchi juga memberikan perlindungan yang baik bagi organisme karena susunan daun yang lebat dan rimbun. Menurut Hadi et al. (2009) serangga yang bertindak sebagai pemakan tumbuhan juga memerlukan tempat untuk berlindung, berkembang biak, atau untuk mengambil makanan.

Tabel 8. JumlahTotal Individu setiap Famili dari Ordo Diptera yang ditemukan di Pertanaman Sacha Inchi selama 18 Pengamatan (5-22 MST)

\begin{tabular}{lccccc}
\hline \multicolumn{1}{c}{ Famili } & $\begin{array}{c}\text { Vegetatif } \\
\text { (ekor) }\end{array}$ & $\begin{array}{c}\text { Generatif } \\
\text { (ekor) }\end{array}$ & $\begin{array}{c}\text { Total } \\
\text { (ekor) }\end{array}$ & $\begin{array}{c}\text { Persentase } \\
(\%)\end{array}$ & Peran \\
\hline Chironomidae & 7 & 26 & 33 & 1,18 & Pengurai \\
Lonchopteridae & 14 & 19 & 33 & 1,18 & Pengurai \\
Chaoboridae & 1 & 1 & 2 & 0,07 & Predator \\
Chloropidae & 6 & 64 & 70 & 2,51 & Hama, Pengurai, \\
Dolichopodidae & 7 & 44 & 51 & 1,83 & Predator \\
Blephaceridae & 1 & 208 & 209 & 7,50 & Predator \\
Psychodidae & 9 & 2128 & 2137 & 76,70 & Pengurai \\
Stratiomyidae & 5 & 134 & 139 & 4,99 & Pollinator \\
Sepsidae & 1 & 0 & 1 & 0,04 & Pengurai \\
Milichiidae & 3 & 4 & 7 & 0,25 & Pengurai \\
Platystomatidae & 2 & 0 & 2 & 0,07 & Hama \\
Micropezidae & 3 & 1 & 4 & 0,14 & Pengurai \\
Scathophagidae & 1 & 4 & 5 & 0,18 & Pengurai \\
Tephritidae & 1 & 2 & 3 & 0,11 & Hama \\
Fanniidae & 2 & 14 & 16 & 0,57 & Pengurai \\
Anthomyzidae & 1 & 0 & 1 & 0,04 & Pengurai \\
Asilidae & 1 & 8 & 9 & 0,32 & Predator \\
Diopsidae & 0 & 5 & 5 & 0,18 & Pengurai \\
Bibionidae & 0 & 31 & 31 & 1,11 & Pengurai \\
Celyphidae & 0 & 4 & 4 & 0,14 & Pengurai \\
Tabanidae & 0 & 1 & 1 & 0,04 & Pollinator \\
Lauxaniidae & 0 & 13 & 13 & 0,47 & Pengurai \\
Psillidae & 1 & 0 & 1 & 0,04 & Hama \\
Bombylidae & 5 & 4 & 9 & 0,32 & Pollinator \\
\hline
\end{tabular}


Saat tanaman memasuki fase generatif, jumlah famili Psychodidae, Blephaceridae dan Stratiomyidae merupakan famili yang paling tinggi (Tabel 8). Hal ini kemungkinan karena ketiga jenis lalat tersebut tertarik pada bunga sacha inchi. Imago Stratiomyidae berperan sebagai pollinator dan larvanya berperan dalam biokonversi sampah organik sehingga tidak termasuk hama dan sangat membutuhkan air untuk mempertahankan hidup dan bereproduksi (Wangko, 2014). Menurut Mann et al. (2015), imago Psychodidae memakan nektar dan getah tanaman. Psychodidae pada fase larva tinggal di dalam air yang mengalir dan memakan hewan yang lebih kecil yang berada di dalam air (Borror et al. 1992).

Menurut Jumar (2000), Diptera dewasa banyak dijumpai di bunga-bunga sehingga peningkatan jumlah pada pengamatan akhir menjadi relevan. Selain itu dengan adanya hujan menambah kelembapan udara yang semakin tinggi. Hal ini membuat famili Psychodidae, Blephaceridae, dan Stratiomyidae yang menyukai kelembapan semakin banyak berada di pertanaman sacha inchi.

Tabel 9. Jumlah Total Individu setiap Famili dari Ordo Lepidoptera yang ditemukan di Pertanaman Sacha Inchi selama 18 Pengamatan (5-22 MST)

\begin{tabular}{lccccc}
\hline Famili & Vegetatif (ekor) & Generatif (ekor) & Total (ekor) & Persentase (\%) & Peran \\
\hline Lymantriidae & 63 & 13 & 76 & 47,50 & Hama \\
Nymphalidae & 4 & 2 & 6 & 3,75 & Hama \\
Pyralidae & 13 & 3 & 16 & 10,00 & Hama \\
Psychidae & 11 & 45 & 56 & 35,00 & Hama \\
Pieridae & 1 & 1 & 2 & 1,25 & Hama \\
Gelechiidae & 3 & 1 & 4 & 2,50 & Hama \\
\hline
\end{tabular}

Diantara ordo Lepidoptera, Famili Lymantriidae, Pyralidae, dan Psychidae paling banyak ditemukan (Tabel 9). Menurut Broderick et al. (2000), Lymanriidae merupakan pemakan daun yang paling merusak dan ketika terjadi ledakan populasi dapat menyebabkan kerusakan parah pada pertanaman di hutan dan mempengaruhi pertumbuhan dan kelangsungan hidup pohon, kualitas air dan tanah, serta habitat hewan di sekitarnya.
Perubahan morfologi dan fisiologi tanaman dan lingkungan, seperti turun hujan di pengamatan akhir, menyebabkan perubahan populasi Lepidoptera. Menurut Suputa (2011), naiknya temperatur dapat mempercepat siklus hidup Lymantriidae. Pada penelitian ini, saat tanaman fase vegetatif curah hujan 0 (Tabel 1) sehingga berpengaruh terhadap kecepatan perkembangbiakan Lymantriidae yang ditunjukkan pada tingginya populasi (Tabel 9).

Tabel 10. Jumlah Total Individu setiap Famili dari Ordo Hymenoptera yang Ditemukan di Pertanaman Sacha Inchi selama 18 Pengamatan (5-22 MST)

\begin{tabular}{lccccc}
\hline Famili & $\begin{array}{c}\text { Vegetatif } \\
\text { (ekor) }\end{array}$ & $\begin{array}{c}\text { Generatif } \\
\text { (ekor) }\end{array}$ & $\begin{array}{c}\text { Total } \\
\text { (ekor) }\end{array}$ & $\begin{array}{c}\text { Persentase } \\
(\%)\end{array}$ & Peran \\
\hline Formicidae & 9.959 & 5.946 & 15.924 & 99,90 & Hama, Pengurai \\
Apidae & 2 & 2 & 4 & 0,03 & Polinator \\
Vespidae & 0 & 5 & 5 & 0,03 & Predator, Polinator \\
Ichneumonidae & 1 & 2 & 3 & 0,02 & Parasitoid \\
Braconidae & 3 & 1 & 4 & 0,03 & Parasitoid \\
\hline
\end{tabular}

Ordo Hymenoptera yang datang ke pertanaman sacha inchi terdiri atas 5 famili, yaitu Formicidae, Apidae, Vespidae, Ichneumonidae, dan Braconidae (Tabel 10). Famili Formicidae (kelompok semut) paling banyak ditemukan baik saat tanaman fase vegetatif maupun generatif. Serangga ini hidup dalam koloni atau kelompok meskipun berada dalam satu tanaman. Menurut Lima dan Antonialli-Jr (2013), aktivitas mencari makan Formicidae dapat dipengaruhi oleh temperatur, kelembapan, radiasi, angin, dan faktor abiotik yang lain, yang kesemuanya mempengaruhi penggunaan energi selama mencari makan. Selain itu iklim mikro, yaitu suhu 
menjadi faktor penentu keragaman dan komposisi semut (Ikbal et al., 2014). Pada pertanaman sacha inchi, semut ditemukan memakan cairan tanaman dan benih yang sedang berkecambah (Gambar 2).
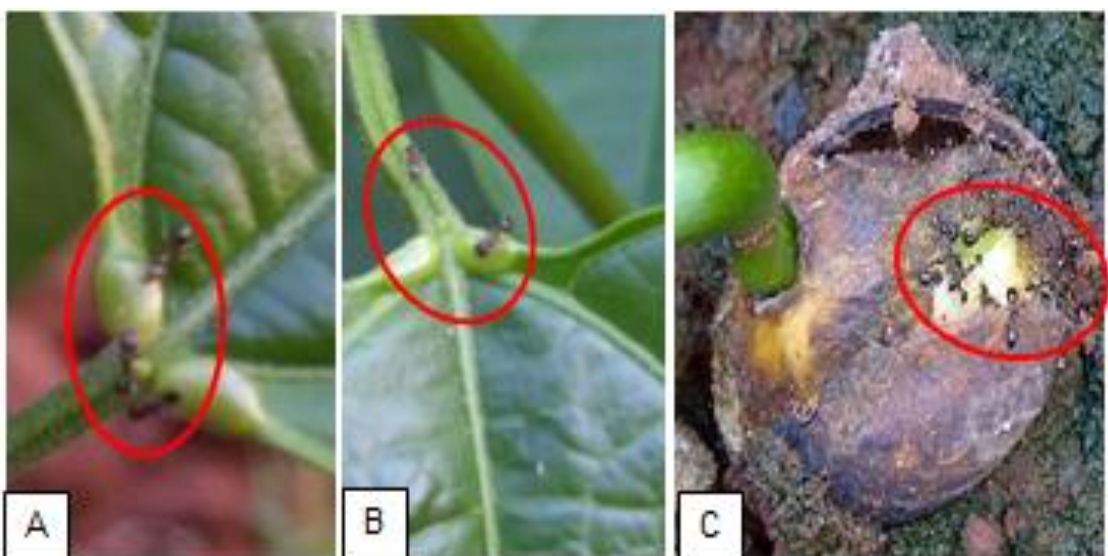

Gambar 2. A-B. Semut yang Makan Cairan Tanaman Sacha Inchi. C. Semut yang makan benih Sacha Inchi

\section{Keberadaan Arthropoda}

Arthropoda datang ke suatu pertanaman dapat berada di berbagai habitat spesifik, antara lain di tanah, perairan, udara, maupun di pertanaman itu sendiri. Di pertanaman, Arthropoda berada di perakaran, daun, batang, bunga, dan buah. Arthropoda yang ditemukan pada pertanaman sacha inchi terbagi dalam $89 \%$ berada di daun, $9 \%$ di bunga, dan $2 \%$ di batang (Gambar 3). Hal ini menunjukkan bahwa secara umum jumlah hama tidak lebih besar dari jenis Arthropoda dengan peran yang lain sehingga kerusakan yang disebabkan oleh hama pada pertanaman masih dapat ditoleransi. Menurut Hadi et al. (2009), proses pemilihan dan penentuan inang oleh serangga sangat dipengaruhi oleh tanaman itu sendiri. Dalam hal ini sifat morfologi dan fisiologi tanaman sehingga adanya perubahan fase tumbuh tanaman sacha inchi akan mempengaruhi kedatangan Arthropoda.

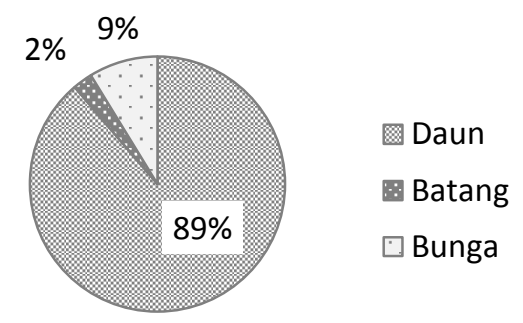

Gambar 3. Grafik Keberadaan Arthropoda pada Tiga Bagian Tanaman Sacha Inchi

\section{Peran Arthropoda}

Arthropoda memiliki peran penting dalam keseimbangan ekosistem. Berdasarkan perannya, Arthropoda dibagi menjadi kelompok hama, musuh alami, dan peran lain seperti pollinator, pengurai, dan lain sebagainya. Hasil pengamatan menunjukkan adanya perbedaan peran dari Arthropoda yang ditemukan (Gambar 4).

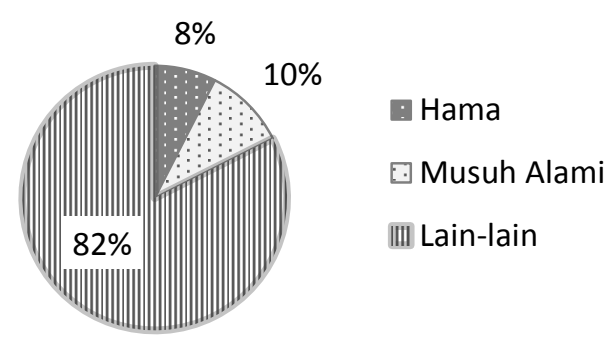

Gambar 4. Peran Arthropoda di Pertanaman Sacha Inchi

Komposisi peran Arthropoda di pertanaman sacha inchi terdiri atas 8\% hama, 10\% musuh alami, dan $82 \%$ pengurai danpolinator. Hama terdiri atas ordo Orthoptera, Homoptera, Coleoptera, Diptera, dan Lepidoptera. Musuh alami paling banyak dari ordo Araneae, Hymepotera, Diptera, dan beberapa dari ordo Orthoptera, Coleoptera, dan Hemiptera. Polinator dan pengurai berasal dari ordo Hymenoptera dan Diptera. Serangga pengurai yang sebagian besar berasal dari kelompok semut, memakan bahan organik berupa bagian tanaman yang membusuk maupun Arthropoda lain yang sudah mati. 


\section{KESIMPULAN DAN SARAN}

\section{Kesimpulan}

Arthropoda yang ditemukan pada pertanaman sacha inchi di lahan kering terdiri dari 75 famili yang berasal dari 13 ordo, yaitu ordo Araneae, Ephemeroptera, Odonata, Orthoptera, Blattaria, Isoptera, Hemiptera, Homoptera, Thysanoptera, Coleoptera, Diptera, Lepidoptera, dan Hymenoptera. Peran Arthropoda di pertanaman sacha inchi yaitu $8 \%$ merupakan hama, $10 \%$ musuh alami baik predator maupun parasitoid, dan $82 \%$ lain-lain (pengurai dan pollinator). Keragaman Arthropoda yang berada di pertanaman sacha inchi di lahan kering masuk dalam kategori rendah dengan nilai indeks keragaman Shannon 0,692 dan indeks kemerataan 0,164 yang menunjukkan bahwa kemerataannya rendah (dominansi tinggi).

\section{Saran}

Saran yang dapat diberikan dari penelitian ini yaitu perlu dilakukan identifikasi Arthopoda sampai ke tingkat spesies sehingga dapat diketahui peran Arthropoda yang lebih mendalam di pertanaman sacha inchi.

\section{DAFTAR PUSTAKA}

Abdurachman, A., Dariah, A., \& Mulyani, A. 2008. Strategi dan Teknologi Pengelolaan Lahan Kering mendukung Pengadaaan Pangan Nasional. J. Litbang Perta. 27(2), 43-49.

Beisel, J.N., Polatera, P.U., Bachmann, V., \& Moreteau, J.C. 2003. A Comparative Analysis of Evenness Index Sensitivity. Internat. Rev. Hydrobiol. 88(1), 3-15.

Borror, D.J., Triplehorn, C.A., \& Johnson, N.F. 1992. Pengenalan Pelajaran Serangga. Ed. 6. Terjemahan oleh S. Partosoedjono, 1992. Yogyakarta: Gadjah Mada University Press.

BPS (Badan Pusat Statistik). 2010. Statistik Indonesia tahun 2010. Badan Pusat Statistik. Jakarta.

Broderick, N.A., Goodman, R.M., Raffa, K.F., \& Handelsman, J. 2000. Synergy between Zwittermicin $\mathrm{A}$ and Bacillis thuringiensis subsp. kurstaki Against Gypsy Moth (Lepidoptera: Lymantriidae). Environment. Ento. 29(1), 101-107.
Cai, Z.Q., Jiao, D.Y., Lei, Y.B., \& Li, W.G. 2013. Growth and Yield Responses of Plukenetia volubilis L. Plants to Planting Density. J. Horticultural Sci. \& Biotech. 88(4), 421-426.

Daly, H.V., Doyen, J.T., \& Ehrlich, P.R. 1978. Introduction to Insect Biology and Diversity. Tokyo: McGraw-Hill Kogakusha.

Gonsebatt, G.G., Viscarret, M.M., \& Lietti, M.M. 2012. Whitefly Species (Hemiptera: Aleyrodidae) on Wild and Cultivated Plants in the Horticultural Region of Rosario, Santa Fe, Argentina. Rev. Soc. Entomol. Argent. 71(1-2), 125-136.

Hadi, H.M., Tarwotjo, U., \& Rahadian, R. 2009. Biologi insekta entomologi. Yogyakarta: Graha Ilmu.

Hamaker, B.R., Valles, C., Gilman, R., \& Hardmeier, R.M. et al. 1992. Amino Acid and Fatty Acid Profiles of the Inca Peanut (Plukenetia volubilis L.). Cereal Chem. 69(4), 461-463.

Ikbal, M., Putra, N.S., \& Martono, E. 2014. Keragaman Semut pada Ekosistem Tanaman Kakao di Desa Banjaroya Kecamatan Kalibawang Yogyakarta. J. Perlind. Tan. Ind. 18(2), 79-88.

Jumar. 2000. Entomologi pertanian. Jakarta: Rineka Cipta.

Komi, M.H.H., Toana, M.H., \& Yunus, M. 2015. Keanekaragaman Arthropoda dan Kepadatan Populasi Imago Pengerek Batang Padi Putih Scirpophaga innotata Wlk. (Lepidoptera: Pyralidae) pada Lingkungan Pertanaman Padi yang berbeda di Kabupaten Parigi Moutong. E-J. Agrotekbis. 3(5), 612-621.

Lilies, S.C. 2008. Kunci Determinasi Serangga. Yogyakarta: Kanisius.

Lima, L.D., \& Antonialli-Jr, W.F. 2013. Foraging Strategies of the Ant Ectatomma vizottoi (Hymenoptera, Formicidae). Revista Brasileira de Entomologia. 57(4), 392-396. DOI: $\quad$ dx.doi.org/10.1590/S008556262013005000038 .

Mann, R.S., Kaufman, P.E., \& Butler, J.F. 2015. A sandy fly, Lutzomyia shannoni Dyar (Insecta: Dipera: Psychodidae: Phlebotomine). Online: http://entnemdept. ifas.ufl.edu/creatures/.

Maulina, F., Nelly, N., Hidrayani, \& Hamid, H. 2016. Keanekaragaman Spesies dan 
Parasitisasi Telur Walang Sangit (Leptocorisa oratorius Fabricus) di Kabupaten Tanah Datar, Sumatera Barat. Pros Sem Nas Masy Biodiv Indon. 2(1), 109-112. DOI: $10.13057 / \mathrm{psnmbi} / \mathrm{m} 020121$.

Mwine, J.T., \& Van, Damme, P. 2011. Why do Euphorbiaceae tick as medicinal plants? A review of Euphorbiaceae family and its medicinal features. J. Med. Plant. Res. 5(5), 652-662.

Nyffeler, M. 1999. Prey Selection of Spiders in the Field. The Journal of Arachnology. 27(1), 317-324.

Oktiana, D., \& Wedi, A. 2015. Keanekaragaman Burung di Lingkungan Unit Pembangkit Indonesia Power (PU IP) Lorong Tambak Semarang. Pros Sem Nas Masy Biodiv Indon. 1(4), 1045-1049.

Suputa. 2011. Ulat bulu hama mangga di Probolinggo. Online: http://faperta.ugm.ac.id /perlintan2005.

Wangko, S. 2014. Hermetia Illucens Aspek Forensik, Kesehatan, dan Ekonomi. $J$. Biomedik. 6(1), 23-29.

Williams, M.L., \& Kosztarab, M. 1972. Morphology and Systematic of the Coccidae of Virginia with Notes and their Biology (Homoptera: coccoidea). Res. Div. Bul. 74. Virginia Polytechnic Institute and State University.

Yang, C., Jiao, Y., Geng, Y.J., Cai, C.T., \& Cai, Z.Q. 2014. Planting Density and Fertilisation Independently Affect Seed and Oil Yields in Plukenetia volubilis L. plants. J. Horticultural Sci. \& Biotech. 89(2), 201-207. 